Article

\title{
The computation of the output gap in Polish economy in the light of the secular stagnation scenario (sustainability antithesis)
}

\author{
Elżbieta Szaruga ${ }^{1, *}$ \\ 1 Institute of Spatial Management and Socio-Economic Geography, University of Szczecin; Mickiewicza 64 \\ Street, Szczecin 71-101, Poland; elzbieta.szaruga@usz.edu.pl \\ * Correspondence: elzbieta.szaruga@usz.edu.pl
}

\begin{abstract}
The research problem was formulated as a question: are demand-supply shocks affecting the opening up of a negative or positive output gap? The hypothesis was formulated: demandsupply shocks have a significant impact on the opening up and deepening of the negative output gap, thereby causing real GDP to shrink or potential GDP to grow. The spatial range applies to Poland and the time period - 2008:Q1-2019:Q4. The methodology consists of three stages: the first is the decomposition of the time series using the TRAMO/SEATS on the components: seasonality, trend-cycle, irregular; the second - the decomposition of the trend-cycle component using the Hodrick-Prescott filter into two separate components; the third is the calculation of the output gap; forecast with VECM and IRF approximation. The ouput gap is in the range of $-11 \%$ to $+10 \%$. After cleaning it, the shock elements are between $-2.2 \%$ and $2 \%$. Demand-supply shocks open up and widen the negative output gap. Based on forecasts, the output gap will be positive by the end of 2022 , close to $0 \%$ (optimal scenario), rising to $5 \%$ (optimistic scenario) and negative, deepening to $4 \%$ (pessimistic scenario). Two of these scenarios point to a growing risk of secular stagnation.
\end{abstract}

Keywords: coronavirus pandemic (2019+); cycle; Hodrick-Prescott filter; output gap; Polish economy; secular stagnation; sustainability; trend

\section{Introduction}

The global economic crisis 2008+ and the crisis associated with the coronavirus pandemic (2019+) highlighted the imperfections of economic policy and economic theories adopted so far. It is noted that in 2020 the crisis 2008+ has not yet ended (despite relatively positive cyclical/conjectural moments as a result of strengthening of internal demand). It can be assumed that it took the next phase of the life cycle, transforming into another crisis, which has its source in supply and demand shocks. Each impulse, this time a coronavirus pandemic 2019+, which affects the imbalance of demand and supply functions, strengthens the effects of the crisis that has already begun. It is believed that the next phase of the crisis's life may be secular stagnation (antithesis of sustainability). In this context the sustainability is a short-term and long-term concept of the development without any deep crises in economy, but economy could drift and be influenced by demand-supply shocks. Sustainability harmonize the orders of modern economies. It should be emphasized that the threat of secular stagnation is increased the more the longer the dominant role of the growth paradigm, the so-called growthmania, is emphasized.

Growthmania is in fact the pursuit of continuous growth, insufficient understanding of the limits of growth and ultimately fetishism of GDP. This fetishism is manifested not only in the construction of indicators containing GDP in their structure (despite its many imperfections), but also analysing the economic situation solely based on GDP cycles, or estimating the output (product) gap in isolation from social and environmental spheres. This problem seems to be "swollen" due to the lack of an alternative indicator that could relate to a long time perspective. New suggestions for indicators are justified and desirable. However, either their frequency of publication is rare (once a year; annual 
data), or the width of the time range is insufficient (too few observations for some analyses), or both. Therefore, one approaches alternative indicators for GDP with a distance (maybe distrust), focusing on the traditional approach.

The paper also focuses on the analysis of GDP and the output gap. Some dilemmas related to the methodical approach to estimating the output gap, containing the irregular (random) component were pointed out. Although the author of this paper notices the problem of growthmania, and also defines GDP in a way, basing analysis on this indicator. However, the essence of this approach is to refer to the problem of estimating the output gap, which is one of the benchmarks in the decisionmaking process of politicians and economists. Because the significance of the output gap is of particular importance not only for the monetary transmission mechanism, but translates into multidimensional effects in the entire economy. Thus, the output gap functions in the constructivist order, in which reality is modelled and in the ecological order, where decisions are made. In addition, it should be noted that this gap is continually affected by short-term and long-term disturbances on both the demand and supply side, therefore its estimation is subject to uncertainty. In other words, the order in which the output gap is forming drifts towards entropy.

The research problem is raised in the form of a question: are demand-supply shocks affecting the opening up of a negative or positive output gap? In the context of this research problem, a research hypothesis has been put forward: Demand-supply shocks have a significant impact on the opening up and deepening of the negative output gap, thereby causing real GDP to shrink or potential GDP to grow. This hypothesis was subordinated to the research objective of computing the output gap and assessing the impulse response from demand-supply shocks to the output gap.

The paper consists of five parts. The first is introduction. The second part discusses the growth paradigm in the context of secular stagnation and reviews the literature regarding the problem of estimating the output gap. The third part introduces the research methodology and describes the data on the basis of which the research related to the estimation of the output gap was carried out. The fourth part is devoted to the presentation of empirical results of estimation output gap along with a detailed description of the stages of research. This section also sets out the response of the output gap to shock and the forecast of the output gap by 2022. The paper ends with summary conclusions.

\section{Literature background}

There is a debate in economics about the directions of socio-economic policy and its future. Until now, economic reality was created by neoliberalism. In could be (or actually should) look for the sources of the global crisis 2008+ and the crisis caused by demand and supply shocks, originally caused by the impulse of a coronavirus pandemic.

The idea of promoting uninterrupted and harmonized development is the sustainable development. Sustainable development is based on harmonization of economic, environmental and social objectives in short-term and long-term decisions. Sustainability is inscribed in the need for development programming [ 1 by 2]. However, economic development based on the idea of sustainable development is not solely focused on economic growth, as in neoliberalism or growthmania. The approach, which is the antithesis of sustainable development [3] (p. 162), is the secular stagnation that is more broadly discussed later in the article.

Elżbieta Mączyńska emphasizes that "neoliberalism is a system that shoots itself in the foot (...)", noting that it focuses exclusively on growth (it is a kind of deification of GDP) without deliberating on social and ecological issues [4] (p. B7).

In this context, the interpretation of pro-growth thinking becomes particularly important. Herman E. Daly aptly called pro-growth thinking devoid of reflection on the limits of growthoriented and mass consumerism - growthmania (about growthmania vide [5] (pp. 149-167)). It is worth mentioning that growthmania is litotes for the concept of de-growth (Serge Latouche raises the issue around the term 'de-growth'. In his opinion, this concept is not synonymous with negative growth, because as Latouche notes, then it would be an oxymoron. However, "de-growth" highlights the fact that modern economies are dominated by the image of growth; by: Latouche [6]). It seems 
that this term is now en vogue in the context of the spectrum of secular stagnation (about secular stagnation vide [7] (pp. 62-69), that is a consequence of the global crisis started in 2007 [8] (p. 11).

Pro-growth thinking is basically conditioned by understanding the idea of economic growth. Józefa Famielec presented the interpretation of the essence of economic growth in the context of economic theory and forward thinking. The professor emphasized that economic growth is of fundamental importance for economics, as it sets the direction of the creators of socio-economic reality, which is why he is considered one of the elementary paradigms. Associating it mainly through the prism of consumer and investment activities, limits its comprehension to the category of GDP or national income - without a clear alternative taking into account other factors (even civilization) [9] (pp. 16-17).

The forecasts of Thomas Piketty [10] (p. 122) correspond well with this understanding of economic growth. Piketty exposes the inability to continue growing like a "hockey stick" ("J" shaped growth - dynamic and infinite growth). Because, as he himself estimates, if growth continues, it is likely that it will not exceed the rate of $1.5 \%$ per year. However, the growth rate that has been observed up to now - at 4-5\% - is, according to Piketty, a historical exception, a temporary situation (in the post-war period in Europe; currently in China, which is catching up with other economies). It is confirmed by the fact that so far no country has permanently maintained a growth rate of more than $1.5 \%$ per year after reaching a point on the technological limit of production capabilities (the original translation uses the wording "world technological frontier") on a global scale [10] (p. 122).

Matthias Schmelzer holds a similar view. According to him, the growth paradigm could be justified until the mid-twentieth century, but nowadays, in a situation of depletion of natural resources and dynamic changes, it is not desirable, and may even be catastrophic [11] (p. 270).

As Hubert Buch-Hansen emphasizes, many economists believe that the rapid growth of economic systems is a leading cause of the environmental crisis and that continuing growth does not allow to overcome the crisis. However, he asks the question whether the transition towards nongrowth economies requires a move away from capitalism [12] (p. 168). It seems that the answer can be found in ordoliberalism.

By extending the above considerations, Józefa Famielec explains that the interferences between the economy are autogenic and based on the laws of nature. She also notes that it could not resort to escapism over the course of these dependencies, but you must model economic processes in harmony with the natural and social environment, which is to serve order - Ordo [13] (p. 114).

The conclusions are confirmation of Naomi Klein, who claims that order is already destabilized, and therefore believes that any steps should be taken to transform "controlled post-growth" (postgrowth is used interchangeably with the word de-growth) from the Great Depression to the "Great Transformation" [14] (p. 100). In other words, it can be argued that N. Klein also notes that the world is falling into entropy and that global economic processes need to be ordered in harmony with other orders, especially environmental ones. She simply proposes to limit consumption through demandregulating tools. This approach should not be confused with the attitudes presented by Will Potter [15] rather than through solutions that promote ecological consumption [14] (pp. 100-101). Opposition to hyper-consumerism seems understandable, but on the other hand, which is associated with a deflation gap, reducing demand can lead to a dangerous deflationary spiral, another crisis and secular stagnation.

In the light of these considerations, the interpretation of secular stagnation is interesting. Panagiotis E. Petrakis, Pantelis C. Kostis and Kyriaki I. Kafka [16] identify the secular stagnation with a new era, new times in economics initiated by the global crisis 2007+. These new times bring inevitable socio-economic changes, thus affecting all participants in the world economy and increasing uncertainty [16] (p. 1910). These unavoidable changes include: a new multipolar and globalized world, excellent competition and market liberalization, hyper-competition, transformation of the economy from industry to services, strengthening of the position of individuals in the conditions of changing globalization, aging of the society, migration problem, climate change, destructive technologies [17].

It is impossible to disagree with this approach, moreover, secular stagnation is a possible scenario in the light of the crisis caused by the coronavirus pandemic. It is believed that a new stage 
in economic life is beginning, a transformation of the economy towards the Internet of Things and the twilight of capitalism [18], although this vision of the world was already proposed after the global economic crisis 2007+. In response to alarming signals from the world of the economy, attention was drawn to the need to measure economic breakdowns. It has been noted that the effects of a deep crisis will always affect the development of the economy in such a way that it will never be possible to close the gap between the current and past state [19] (p. 58). Robert Shiller, writing about the great illusion - yesterday and today, emphasized that along with the evolution of modern weapons of mass destruction, it is necessary to build tools to reduce aggression. According to him, one should move away from the "great illusion" and its consequences by improving financial capitalism, humanization and democratization [20] (p. 330). Perhaps it is worth considering these words in the context of the new reality after the 2019+ coronavirus pandemic. Bernard Landais [21] at the end of his book entitled "Economic fluctuations. A New Synthesis" wrote about additional threats, global opening of economies, and an improperly regulated recession. He noted that free trade protection was a panacea for not getting into the aftermath of the $2007+$ crisis as deeply as it did during the 1930s crisis. He asks the question "And how will it be tomorrow?" [21] (p. 157). His question is valid in the current crisis. In addition, you can ask another question, whether after the experience of coronavirus, the protection of free trade is a panacea for preventing crises.

In the light of this problem, it is worth considering the issue of secular stagnation, which, incidentally, is conditioned, among others, by the spread of the output gap [22] (p. 51). Research on estimating the output gap has been carried out, among others: Álvarez \& Gómez-Loscos [23], Ahmad \& Sharma [24], Łyziak [25], Buncic \& Müller [26], Zhang \& Murasawa [27], Pichette, Robitaille, Salameh, \& St-Amant [28], Marcellino \& Musso [29], Kamada [30], González-Astudillo [31]. Particularly interesting are studies in which the demand gap has been computed using HodrickPrescott filtration, among others: Grant \& Chan [32], Mise, Kim, \& Newbold [33], Razzak [34], Jašová, Moessner, \& Takáts [35], Ince \& Papell [36], Maravall \& del Río [37], Mitra, Maheswari, \& Mitra [38], Amador-Torres, et al. [39], de Carvalho \& Rua [40].

\section{Data, Methods \& Steps}

The research was conducted on the basis of quarterly macroeconomic data, which concerns on Poland and relates to the time range - from first quarter of 2008 to fourth quarter of 2019 (2008:Q12019:Q4). The adopted time range fulfils the condition of the minimum number of the observations in accordance with MQ [41] (p. 14) for the Tramo/Seats method and provides a sufficient number of degrees of freedom for Vector Error Correction Models with accepted delays (which is described in more detail later in the paper). In addition, the adopted time range corresponds to the period assigned to the 2008+ global crisis and the period in which the coronavirus pandemic began (SARS-CoV-2). The following symbol were adopted as representative variable [42]: GDP - gross domestic product at current prices; raw data expressed in mln $€$.

The study was divided into two parts. In the first part, the data was seasonally adjusted using the Tramo/Seats method to reduce the impact of seasonal fluctuations on the tested object - this is particularly important from the point of view of short-term trends, decomposing them into a seasonal, trend-cycle and irregular components. Then the trend-cycle component was decomposed by Hodrick-Prescott filtration for trend and cycle (separately).

The study was divided into two parts. In the first part, the data was seasonally adjusted using the Tramo/Seats method in order to reduce the impact of seasonal fluctuations on the tested object. This is particularly important from the point of view of short-term trends, decomposing them into a seasonal, trend-cycle and irregular components. Then the trend-cycle component was decomposed by the Hodrick-Prescott filtration method [43] for the trend and cycle according to the formula:

$$
\min _{\tau_{t}}\left\{\sum_{t=1}^{T}\left(y_{t}-\tau_{t}\right)^{2}+\lambda \sum_{t=2}^{T-1}\left[\left(\tau_{t+1}-\tau_{t}\right)-\left(\tau_{t}-\tau_{t-1}\right)\right]^{2}\right\}
$$

where:

T number of observation 
$\tau_{t}$ smoothy series,

$y_{t}$ input series.

The second part estimates the output gap. The estimation of the output gap was based on the decomposition of GDP with the Hodrick-Prescott filter. It is calculated as relative difference between real and potential GDP [44]. Calculations were carried out in the Gretl program. The framework of methodology is shown below.

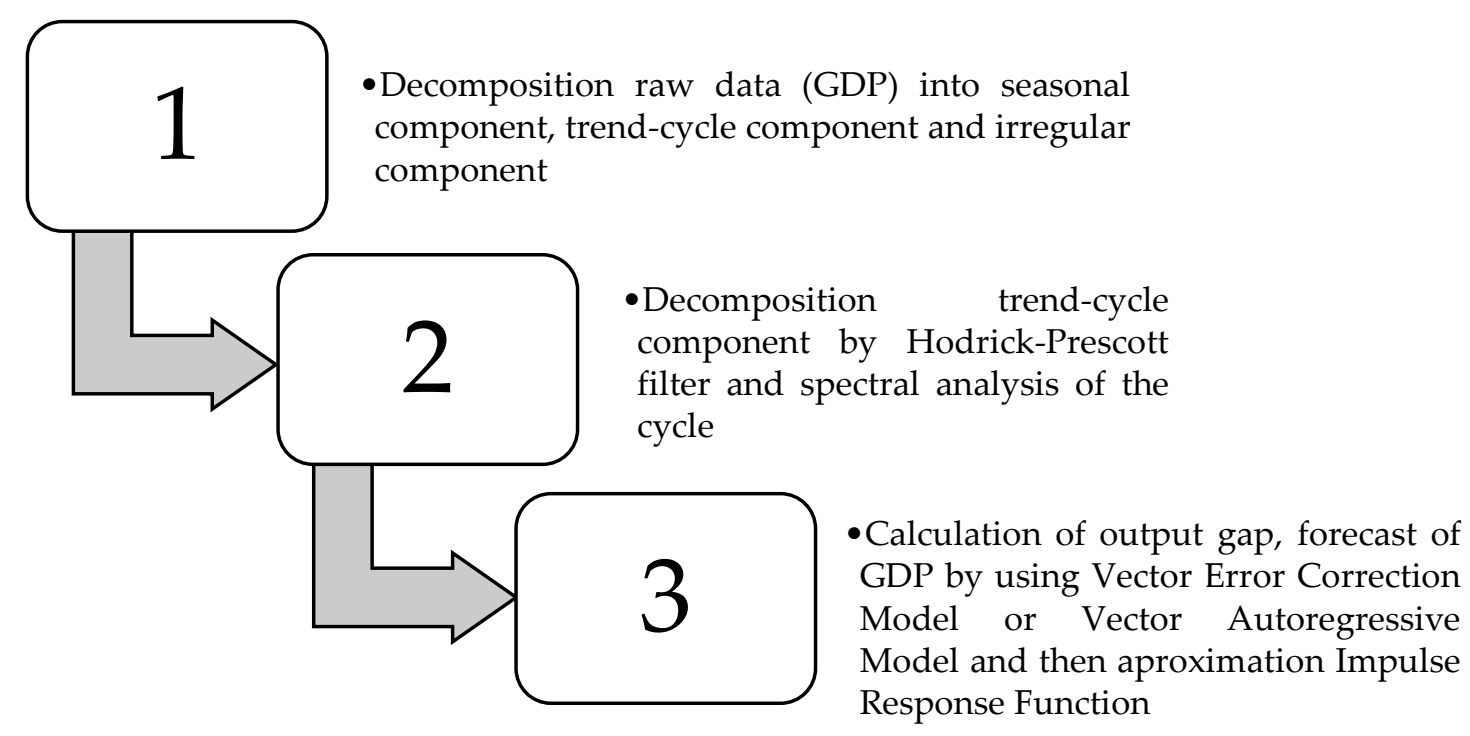

Figure 1. An original proposal for a framework

Source: own elaboration.

The empirical results are shown in the next part of paper.

\section{Empirical results}

In this analysis of the data after taking the logarithm into account, they have been subjected to a decomposition by Tramo/Seats for eliminating seasonal variations [detail in Appendix 1]. However, empirical results are presented for GDP and calculated output gap. Figure 2 shows the decomposition of logarithmic GDP into a seasonal, a trend-cycle and an irregular components. It should be noted that GDP minus the seasonal component is called seasonally adjusted GDP. The seasonally adjusted GDP minus the irregular component should be equal to the trend-cycle component.

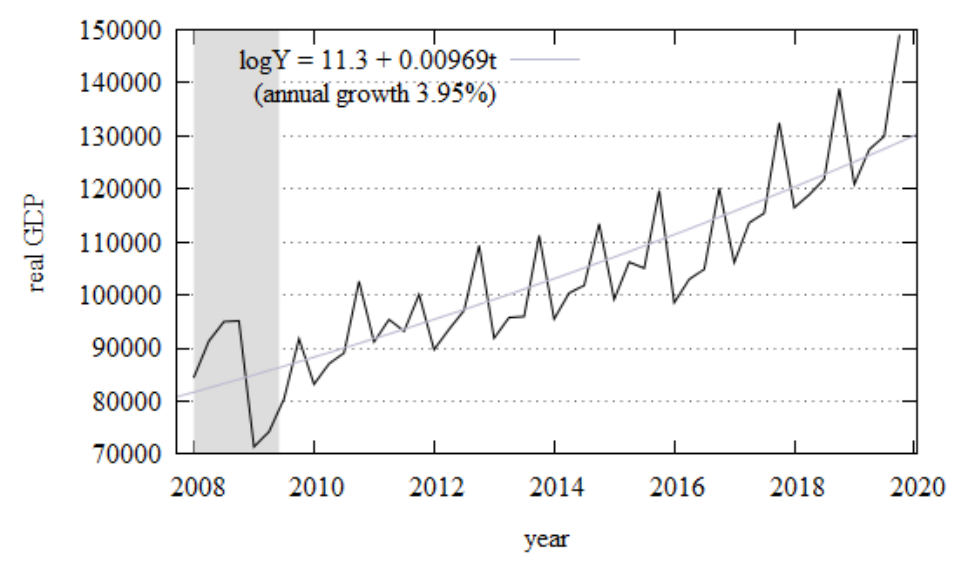



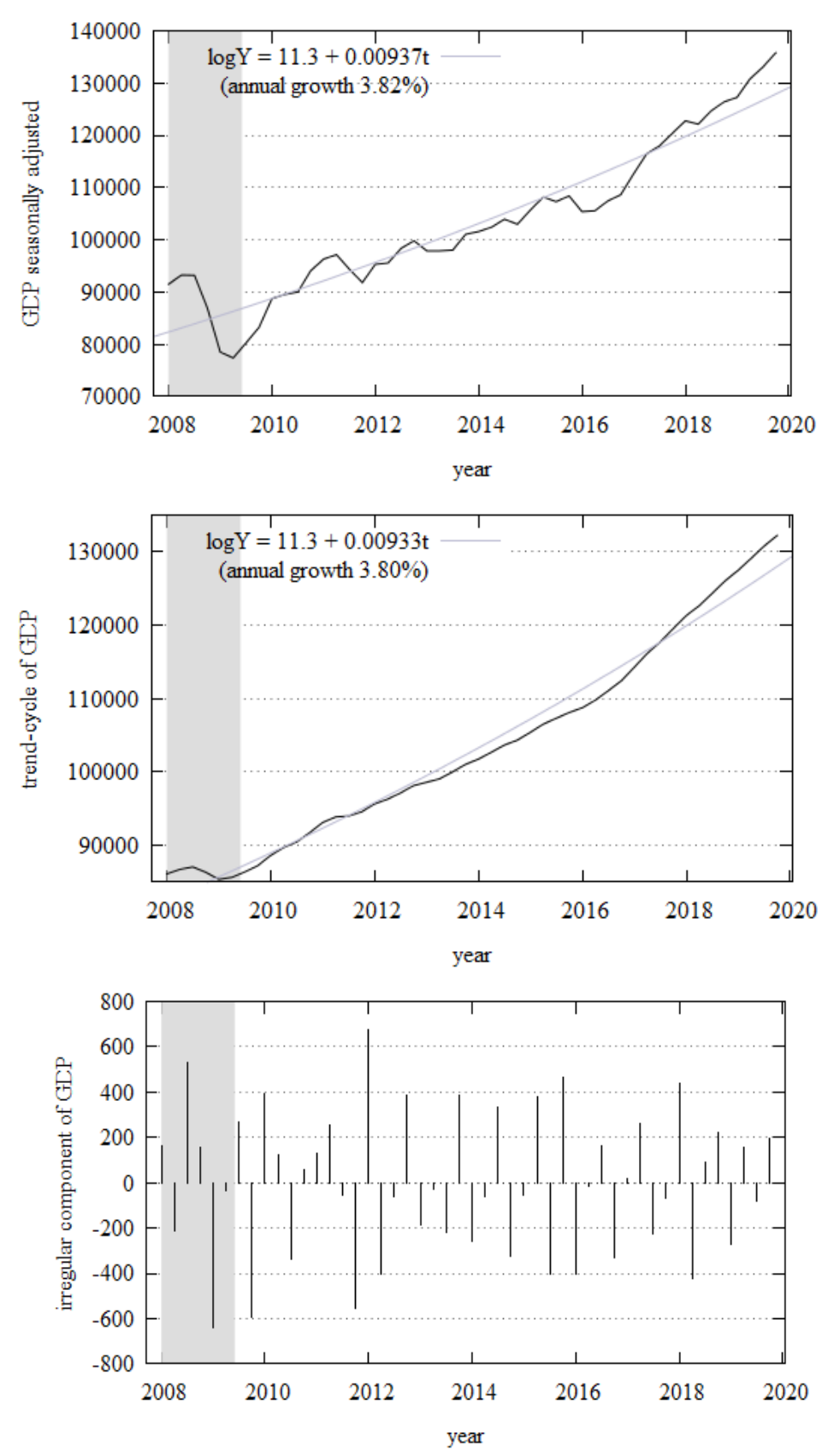

Figure 2. GDP decomposition using the TRAMO/SEATS method

NBER recession is marked in grey colour (zone). The grey line is the best fit line.

Source: own calculations carried out in the Gretl program based on data from the EuroStat database [42].

Based on the graphs in Figure 2, it can be seen that the grey zone is marked NBER recession. NBER recession falls on the period 2008: Q1-2009: Q1, when GDP fell for several consecutive months. In the analysed period, GDP indicates an upward trend and uneven seasonality. Before seasonal adjustment, annual GDP growth was estimated at 3.95\% over the whole period considered, after adjustment at $3.82 \%$. After excluding the irregular component (shock factor) - this increase was estimated at $3.80 \%$, with reference to the aggregate trend and cyclical component. The irregular component had the strongest negative impact in the following periods: 2009:Q1; 2009:Q4; 2011:Q4; 2018:Q2; and positive in: 2008:Q3 and 2012:Q1.

Based on the trend-cycle component, it can be confirmed that the upward trend is maintained throughout the period considered. However, in order to examine the cycle around the long-term 
trend, it was necessary to decompose the trend-cycle component into two separate components using a Hodrick-Prescott filter (figure 3).

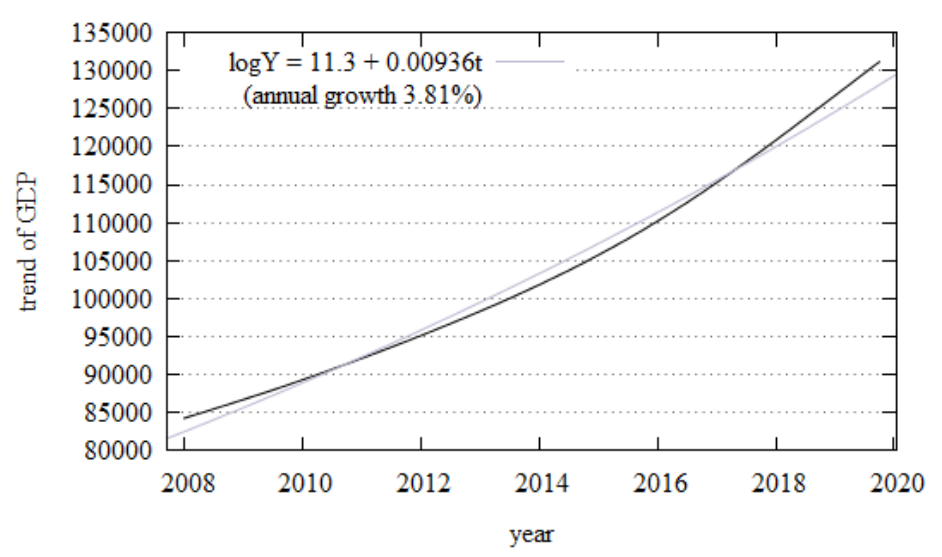

Figure 3. Decomposition of the trend component of GDP by Hodrick-Prescott filter $(\lambda=1600)$

The grey line is the best fit line.

Source: own calculations carried out in the Gretl program based on the results obtained from the Tramo/Seats analysis.

Based on figure 3, it can be seen that the trend component is an increasing function that can be represented as an exponential function (taking into account the previously used logarithmic transformation) as:

$$
\log Y=11.3+0.00936 \mathrm{t} \text {. }
$$

According to this record, the quarterly increase for the GDP trend was $0.9525 \%$, while the annual increase was 3.81\%. The growth dynamics was lower in 2008:Q1-2015:Q4 than in 2016:Q1-2019:Q4.

The next figure (figure 4) presents the decomposed cyclical component of GDP.

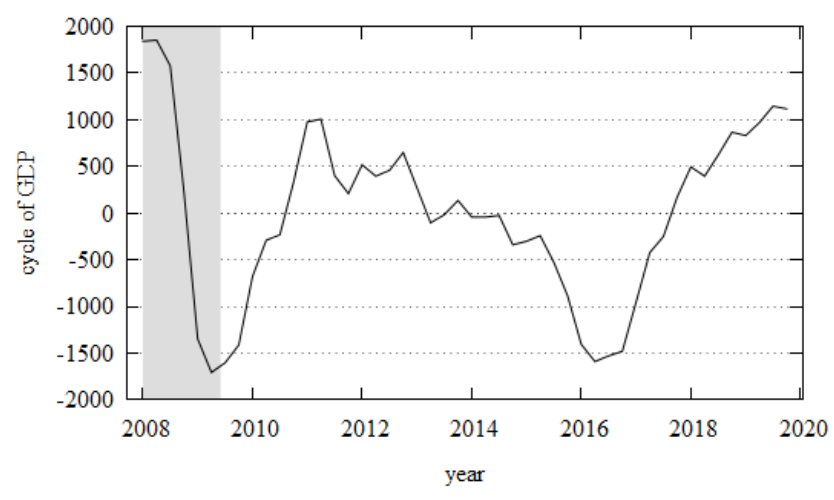

Figure 4. Cycle component of real GDP

NBER recession is marked in grey colour (zone).

Source: own calculations carried out in the Gretl program based on the results obtained from the Tramo/Seats analysis.

Analysing the cyclical component (figure 4), four periods above the long-term trend are distinguished: 2008:Q1-2008:Q4；2010:Q4-2013:Q1；2013:Q4；2017:Q4-2019:Q4. 50\% of the observations are below the long-term trend: 2009:Q1-2010:Q3; 2013:Q2-2013:Q3; 2014:Q1-2017:Q3 (there is also another term, i.e. a secular trend, including in: Osiatyński [45] (pp. 298-299), Block \& Majewski [46] (pp. 67-69). You can see the formation of a flag, consisting of a wedge between the resistance line and the support line (2011:Q2-2014:Q3). The formation of the flag is also interesting (2018:Q1-2019:Q4). The cycle is counted between two depressions, i.e. between the periods 2009:Q2 and 2016:Q2 (7 years). 
The above conclusions are supported by spectral analysis on the length of the business cycle. Table 1 and figure 5 present a periodogram that analysis is based on a stationary cyclic component.

Table 1. Periodogram for cycle component of GDP

\begin{tabular}{cccccccc}
\hline omega & $\begin{array}{c}\text { scaled } \\
\text { frequency }\end{array}$ & periods & $\begin{array}{c}\text { spectral } \\
\text { density }\end{array}$ & omega & $\begin{array}{c}\text { scaled } \\
\text { frequency }\end{array}$ & $\begin{array}{c}\text { spectral } \\
\text { periods }\end{array}$ & \begin{tabular}{c} 
density \\
\hline 0.13
\end{tabular} \\
\hline 1.00 & 48.00 & 303880.00 & 1.70 & 13.00 & 3.69 & 5181.40 \\
\hline 0.26 & 2.00 & 24.00 & 1479500.00 & 1.83 & 14.00 & 3.43 & 23117.00 \\
\hline 0.39 & 3.00 & 16.00 & 521040.00 & 1.96 & 15.00 & 3.20 & 1449.00 \\
\hline 0.52 & 4.00 & 12.00 & 284630.00 & 2.09 & 16.00 & 3.00 & 1129.00 \\
\hline 0.65 & 5.00 & 9.60 & 357590.00 & 2.23 & 17.00 & 2.82 & 8371.20 \\
\hline 0.79 & 6.00 & 8.00 & 41835.00 & 2.36 & 18.00 & 2.67 & 3713.40 \\
\hline 0.92 & 7.00 & 6.86 & 24670.00 & 2.49 & 19.00 & 2.53 & 1474.30 \\
\hline 1.05 & 8.00 & 6.00 & 68119.00 & 2.62 & 20.00 & 2.40 & 488.43 \\
\hline 1.18 & 9.00 & 5.33 & 45813.00 & 2.75 & 21.00 & 2.29 & 518.93 \\
\hline 1.31 & 10.00 & 4.80 & 6635.10 & 2.88 & 22.00 & 2.18 & 514.01 \\
\hline 1.44 & 11.00 & 4.36 & 265.37 & 3.01 & 23.00 & 2.09 & 575.11 \\
\hline 1.57 & 12.00 & 4.00 & 1431.90 & 3.14 & 24.00 & 2.00 & 556.50
\end{tabular}

Cyclic component was previously subjected to stationary testing with an ADF test: optimal delay for the ADF test $=4$ (according to AIC); model: $(1-\mathrm{L}) \mathrm{y}=(\mathrm{a}-1)^{*} \mathrm{y}(-1)+\ldots+\mathrm{e} ; 1$ st-order autocorrelation coeff. for e: 0.169; lagged differences: $\mathrm{F}(4,38)=10.723$ [0.0000]; estimated value of $(\mathrm{a}-1)$ : -0.106036 ; test statistic: tau_nc $(1)=-1.75418$; asymptotic $p$-value 0.07543 . Therefore. the null hypothesis about the occurrence of the unit root a $=1$. process I (1) should be rejected in favour of the hypothesis about stationary series.

Source: own calculations carried out in the Gretl program based on the results obtained for the cyclical component with Hodrick-Prescott filter decomposition.

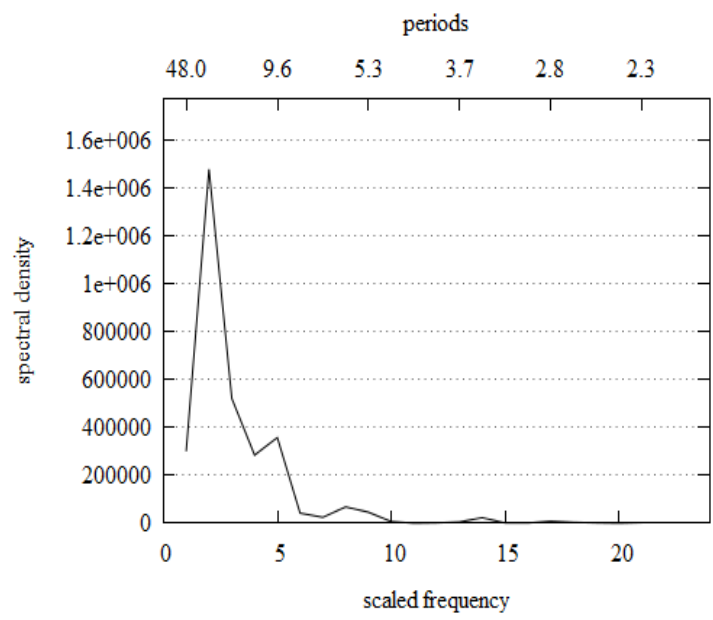

Figure 5. Periodogram of the cycle component of real GDP

Source: own calculations carried out in the Gretl program based on the results obtained for the cyclical component with Hodrick-Prescott filter decomposition.

Based on figure 5, it can be seen that the cyclical nature of real GDP is shaped by four types of business cycles. The first lasting 24 quarters (6 years), the second lasting 9.60 quarters, the third lasting 6 quarters and the fourth - 3.69 quarters. The 6-year and 9.60-quarter cycle is dominant. However, it is worth emphasizing that "leakage" occurs between cycles. It is possible to eliminate the leakage effect by changing the observation. Due to the specifics of the research, it was assumed that the output gap can be shaped by overlapping cycles of different lengths. 
As mentioned before, decomposition with the Hodrick-Prescott filter is of fundamental importance in estimating the output gap (figure 6 and figure 7).

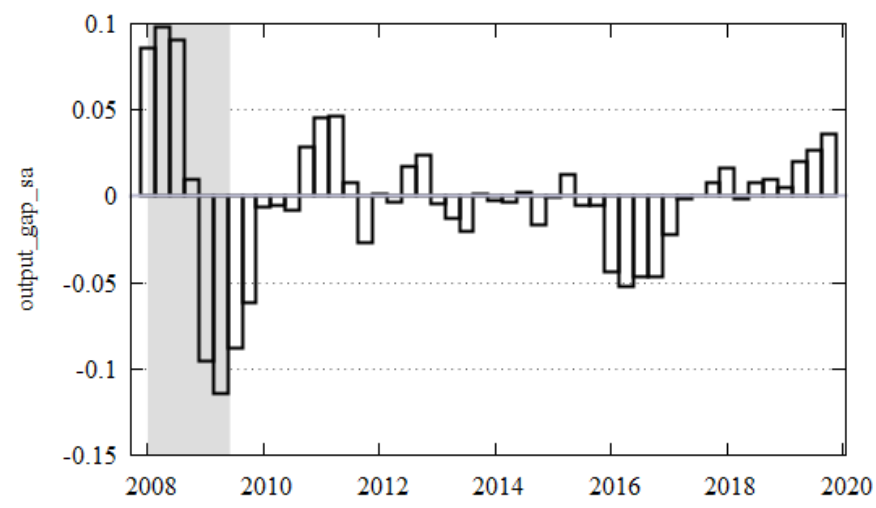

Figure 6. Output gap (\% of potential GDP seasonally adjusted)

Source: own calculations carried out in the Gretl program based on the results obtained for the trend component with Hodrick-Prescott filter decomposition and seasonally adjusted GDP from decomposition by the Tramo/Seats method.

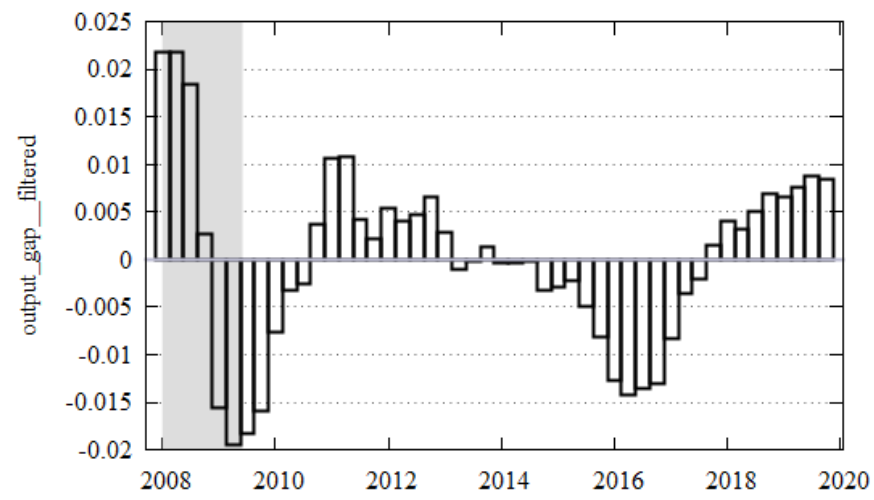

Figure 7. Output gap (\% of potential GDP filtered)

Output gap was previously subjected to stationary testing with an ADF test: optimal delay for the ADF test $=4$ (according to AIC); model: $(1-\mathrm{L}) \mathrm{y}=(\mathrm{a}-1)^{*} \mathrm{y}(-1)+\ldots+\mathrm{e}$; 1st-order autocorrelation coeff. for e: 0.159; lagged differences: $F(4,38)=11.420$ [0.0000]; estimated value of $(a-1)$ : -0.129988; test statistic: tau_nc(1) =-2.07994; asymptotic p-value 0.03605 . Therefore. the null hypothesis about the occurrence of the unit root $\mathrm{a}=1$. process I (1) should be rejected in favour of the hypothesis about stationary series.

Source: own calculations carried out in the Gretl program based on the results obtained for the trend component with Hodrick-Prescott filter decomposition and corrected GDP (eliminated seasonality and irregular component) from decomposition by the Tramo/Seats method.

As can be seen from figure 6, the output gap related to potential seasonally adjusted GDP would even reach around 10\% in 2008:Q2 and 2008:Q3 and around -10\% in 2009:Q1 and around $-11 \%$ in 2009:Q2. These values would be overestimated by an irregular component (among others: shocks, innovations, crisis and other phenomena referred to as the "Black Swan" derived from the title of the book [47].

Based on the output gap cleared of an irregular component (figure 7), that contains sources of uncertainty, shocks, innovations and other impulses for the economy, one could see a reduction in its level. The cleaned output gap reaches a maximum of approx. $2.2 \%$ or a minimum of approx. $-2 \%$. This level of the demand gap, calculated by the Tramo/Seats method in order to decompose into 
individual components (taking into account seasonal adjustment) and then subjected to filtration and purification from an irregular component.

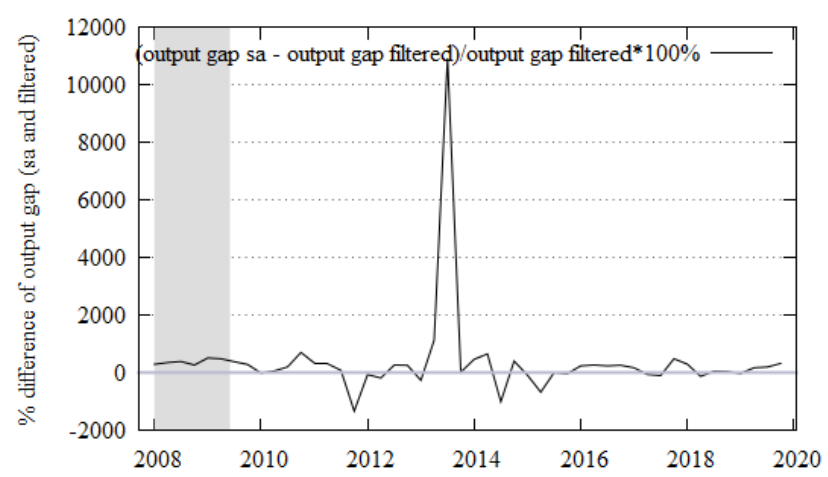

Figure 8. Relative difference of output gap (in \%)

Relative difference of output gap = (output gap sa - output gap filtered $) /$ output gap filtered ${ }^{*} 100 \%$. Relative difference of output gap was previously subjected to stationary testing with an ADF test: optimal delay for the ADF test $=4$ (according to AIC); model: $(1-\mathrm{L}) \mathrm{y}=(\mathrm{a}-1)^{*} \mathrm{y}(-1)+\ldots+$ e; 1st-order autocorrelation coeff. for e: 0.007 ; lagged differences: $F(2,42)=0.169$ [0.8451]; estimated value of (a 1): -0.807329 ; test statistic: tau_nc(1) $=-3.27519$; asymptotic p-value 0.001033 . Therefore. the null hypothesis about the occurrence of the unit root $\mathrm{a}=1$. process $\mathrm{I}(1)$ should be rejected in favour of the hypothesis about stationary series.

Source: own calculations.

When comparing figures 6 and 7, the irregular component overestimates the output gap from approx. $5 \%$ to $10921 \%$ (module with $+/$ - value). The highest revaluation modules would be recorded for the following periods (figure 8): 2013:Q2 (10921.00\%); 2011:Q4 (-1334.50\%); 2013:Q2 (1130.85\%); 2014:Q3 (-1010.52\%).

Figure 9 shows the impact of the demand-supply shock in GDP, which affects the deepening of the output gap. In time from the shock, this meltdown exacerbates the negative output gap. Since the 13th quarter, the impulse has remained constant negative levels without dredging over time.

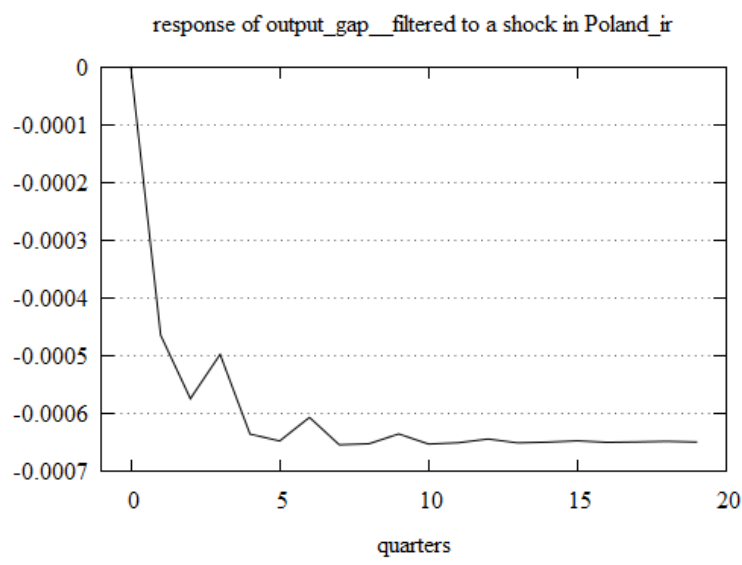

Figure 9. Response of output gap to shock of GDP (in \%)

Source: own computations on the basis of Impulse Response Function from Vector Error Correction Model.

Figure 9 shows a forecast for the output gap from 2020:Q1-2021:Q4. 


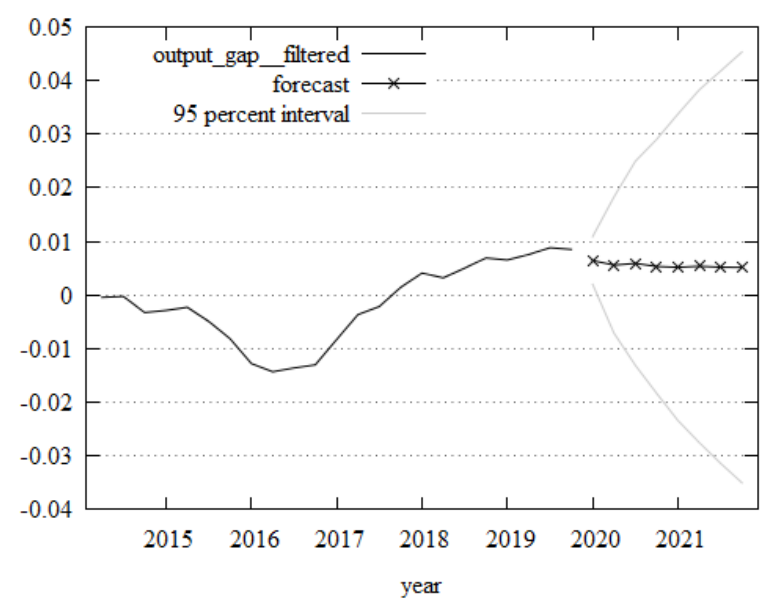

Figure 10. Forecast of output gap of GDP (in \%)

Source: own computations on the basis of Vector Error Correction Model.

The output gap is likely to remain slightly positive, but it will push for a closure and move towards a negative output gap under the shock of the pandemic of coronavirus (2019+). After about 13 quarters, that is, at the turn of 2022/2023 it will turn into a negative gap. However, if the shock caused by the pandemic of coronavirus deepens, the output gap could even reach $-4 \%$ of GDP, or if domestic demand were strengthened through an active socio-economic policy it could reach around $+5 \%$ of GDP.

\section{Discussion}

On the basis of the above research results, it can be made clear that GDP is being influenced by a growing trend, leaking cycles and seasonality. At the same time, shocks of varying severity and direction of action are hidden in it. Reducing non-anticipated changes of a random (shock) nature reduces the demand gap (outside the narrow time range) and captures non-random inflection points. This is in line with the fact that supply-demand shocks increase the span between real and potential GDP, opening up or deepening the demand gap, particularly in the minus. It should therefore be noted that a shock component has a significant impact on the opening of the output gap. It also has a long delay, which is important for building short-term and long-term forecasts.

In subsequent studies, the analysis of the output gap should be extended by the conjectural clock and Vector Error Correction Models (VECM). The next step in this study would be a comparative analysis of the output gap using both (1) the decomposition technique (preceded by the TRAMO/SEATS analysis) and (2) the structural VEC models that are not presented in this article. However, they have been used to estimate impulse response function and forecast. An indispensable element would also be the reference to the Phillips curve and the extension of models with additional quasi-exogenous and endogenous variables.

\section{Conclusions}

The assessment of the output gap in the light of secular stagnation (sustainability antithesis) is important as it shows the span between potential and real GDP. In the event of a negative output gap, demand barriers and slow growth (including development) can be found. However, the output gap primarily expresses the inability to adapt development potential to its economic resources and thus the scale of non-harmonisation of sustainable development.

The loss of the possibility of this adaptation is mainly influenced by shocks of different origins. These can be demand-supply shocks, structural, political, social or environmental shocks (such as the corona pandemic). It is therefore extremely important to build scenarios for the development of the 
output gap under shocks and without their participation. This allows to assess the scale of the "clean" output gap (without shocks) and the output gap created by shocks of different origins.

An occurrence of at least one shock associated with the source of Alvin Hansen's secular stagnation causes a slowdown in demand and the balancing process. In the age of the corona virus pandemic, one of the sources of secular stagnation, such as the limitation of territorial expansion, is noted, which indirectly reduces globalisation. This adversely affects the conditions of development, the increase in its dynamics and the flow of knowledge, resources and investment.

Author Contributions: E.S. created the conceptualization; prepared resources; described methodology; conducted formal analysis; carried out investigation; supervised the work; watched over the administration; wrote the paper.

Funding: The project is financed within the framework of the program of the Minister of Science and Higher Education under the name "Regional Excellence Initiative" in the years 2019 - 2022; project number 001/RID/2018/19; the amount of financing PLN 10,684,000.00.

Conflicts of Interest: The authors declare no conflict of interest.

\section{Appendix A. SIGNAL EXTRACTION IN 'ARIMA' TIME SERIES}

\section{REDUCED OUTPUT}

\begin{tabular}{lcccc}
\multicolumn{5}{l}{ SERIES TITLE: Poland } \\
PREADJUSTED WITH TRAMO : & YES & \\
NO OF OBSERVATIONS $=48$ & & \\
X 10.0D 3 & & & & \\
YEAR & 1ST & 2ND & 3RD & 4TH \\
2008 & 84.523 & 91.375 & 94.987 & 95.140 \\
2009 & 71.380 & 74.219 & 80.420 & 91.758 \\
2010 & 83.189 & 87.044 & 89.075 & 102.579 \\
2011 & 91.161 & 95.381 & 93.184 & 100.090 \\
2012 & 89.702 & 93.531 & 97.113 & 109.333 \\
2013 & 91.869 & 95.753 & 95.952 & 111.232 \\
2014 & 95.485 & 100.379 & 101.805 & 113.426 \\
2015 & 99.152 & 106.213 & 105.063 & 119.696 \\
2016 & 98.547 & 102.949 & 104.853 & 120.145 \\
2017 & 106.113 & 113.623 & 115.416 & 132.455 \\
2018 & 116.466 & 118.913 & 121.861 & 138.923 \\
2019 & 120.874 & 127.438 & 129.920 & 148.878
\end{tabular}

TRANSFORMATION: Z -> Z

NONSEASONAL DIFFERENCING $\mathrm{D}=0$

SEASONAL DIFFERENCING $\quad \mathrm{BD}=1$

TYPE OF ESTIMATION: MAXIMUM LIKELIHOOD

MODEL FITTED

$\begin{array}{lccc}\text { NONSEASONAL } & \mathrm{P}=0 & \mathrm{D}=0 & \mathrm{Q}=3 \\ \text { SEASONAL } & \mathrm{BP}=0 & \mathrm{BD}=1 & \mathrm{BQ}=1\end{array}$ 


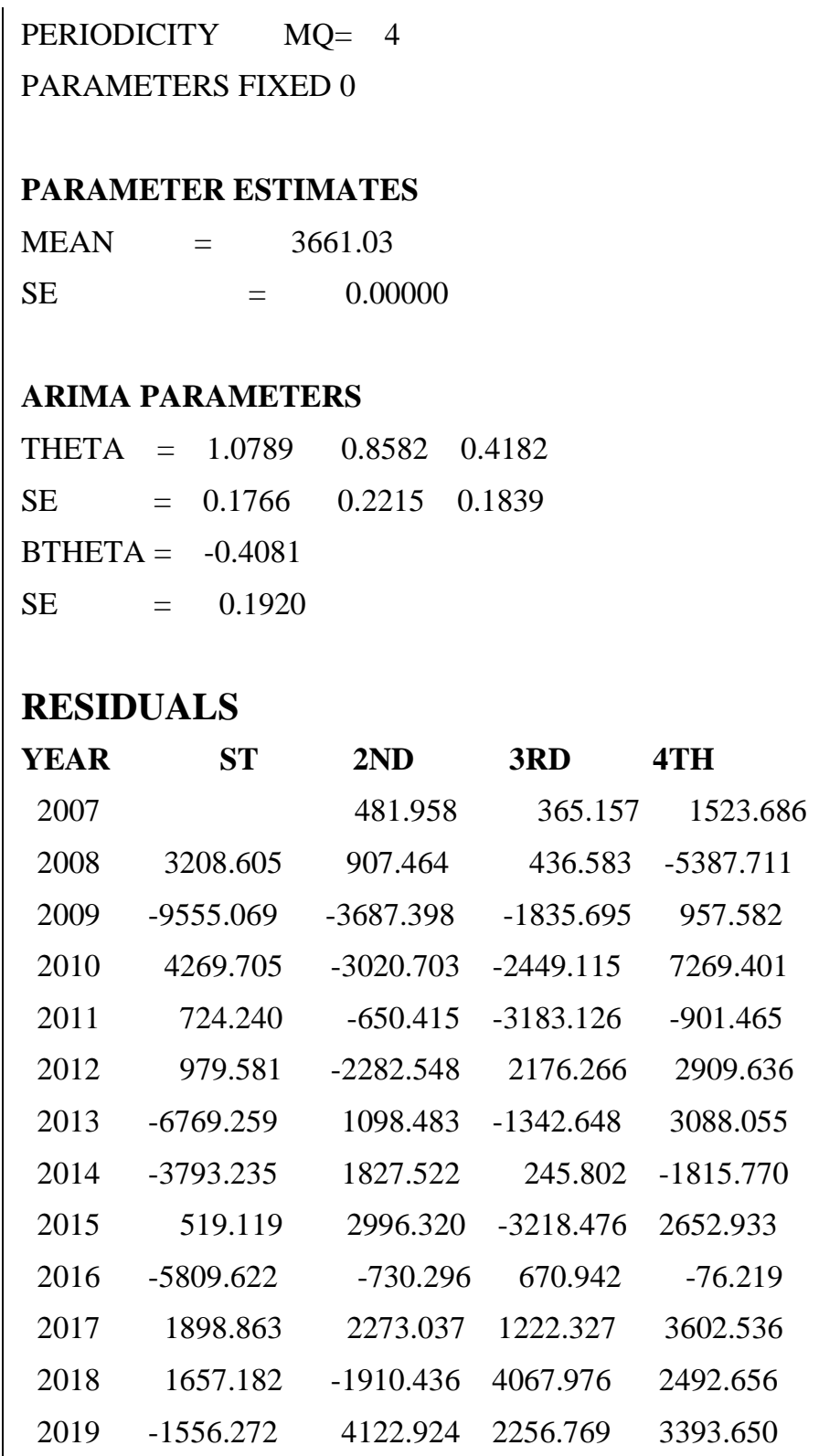

\section{RESIDUALS STATISTICS}

$\begin{array}{ll}\mathrm{MEAN}=0.1240 \mathrm{E}+03 & (\mathrm{SE}=437.6360) \\ \mathrm{SKEWNESS}=-0.6916 \mathrm{E}+00 & (\mathrm{SE}=0.3430) \\ \text { KURTOSIS }=0.3749 \mathrm{E}+01 & (\mathrm{SE}=0.6860) \\ \text { STANDARD DEVIATION }= & 0.3577 \mathrm{E}+04\end{array}$

AUTOCORRELATIONS OF RESIDUAL

$\begin{array}{cccccccc} & 0.0587 & 0.0342 & 0.0308 & -0.0987 & -0.0316 & 0.0280 \\ \text { SE } & 0.1400 & 0.1405 & 0.1407 & 0.1408 & 0.1422 & 0.1423 \\ & & & & & & \\ & & -0.1067 & 0.0856 & -0.1706 & 0.1734 & 0.1266 & 0.0433 \\ \text { SE } & 0.1424 & 0.1440 & 0.1450 & 0.1488 & 0.1527 & 0.1548\end{array}$




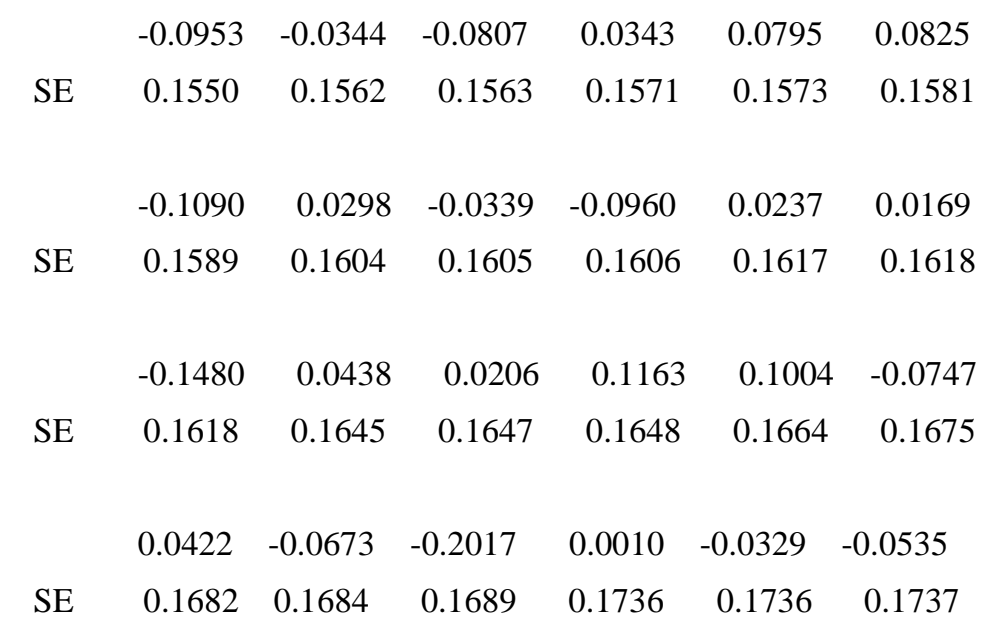

THE LJUNG-BOX Q VALUE IS $\quad 7.67$

IF RESIDUALS ARE RANDOM IT SHOULD BE DISTRIBUTED AS CHI-SQUARED (12)

TRANSFORMATION: Z -> Z

NONSEASONAL DIFFERENCING $\mathrm{D}=0$

SEASONAL DIFFERENCING $\quad \mathrm{BD}=1$

TYPE OF ESTIMATION : MAXIMUM LIKELIHOOD

MODEL FITTED

$\begin{array}{lcll}\text { NONSEASONAL } & \mathrm{P}=0 & \mathrm{D}=0 & \mathrm{Q}=3 \\ \text { SEASONAL } & \mathrm{BP}=0 & \mathrm{BD}=1 & \mathrm{BQ}=1 \\ \text { PERIODICITY } & \mathrm{MQ}= & & \\ \text { PARAMETERS FIXED } 0 & & \\ \text { PARAMETER ESTIMATES } & \\ \text { MEAN }= & 3661.03 & \\ \text { SE }= & 0.00000\end{array}$

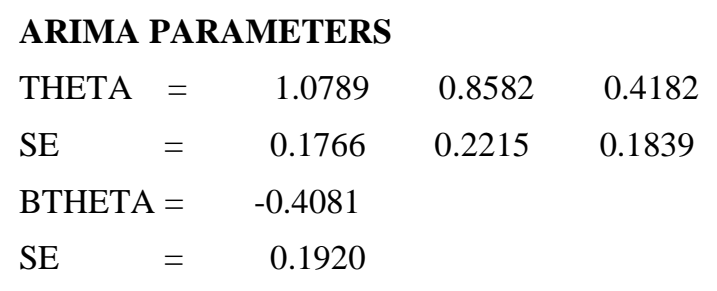

\section{RESIDUALS}

$\begin{array}{lcccc}\text { YEAR } & \text { 1ST } & \text { 2ND } & \text { 3RD } & \text { 4TH } \\ 2007 & & 481.958 & 365.157 & 1523.686 \\ 2008 & 3208.605 & 907.464 & 436.583 & -5387.711 \\ 2009 & -9555.069 & -3687.398 & -1835.695 & 957.582 \\ 2010 & 4269.705 & -3020.703 & -2449.115 & 7269.401 \\ 2011 & 724.240 & -650.415 & -3183.126 & -901.465 \\ 2012 & 979.581 & -2282.548 & 2176.266 & 2909.636 \\ 2013 & -6769.259 & 1098.483 & -1342.648 & 3088.055\end{array}$




$\begin{array}{ccccc}2014 & -3793.235 & 1827.522 & 245.802 & -1815.770 \\ 2015 & 519.119 & 2996.320 & -3218.476 & 2652.933 \\ 2016 & -5809.622 & -730.296 & 670.942 & -76.219 \\ 2017 & 1898.863 & 2273.037 & 1222.327 & 3602.536 \\ 2018 & 1657.182 & -1910.436 & 4067.976 & 2492.656 \\ 2019 & -1556.272 & 4122.924 & 2256.769 & 3393.650\end{array}$

\section{RESIDUALS STATISTICS}

$\mathrm{MEAN}=0.1240 \mathrm{E}+03 \quad(\mathrm{SE}=437.6360)$

SKEWNESS $=-0.6916 \mathrm{E}+00 \quad(\mathrm{SE}=0.3430)$

KURTOSIS $=0.3749 \mathrm{E}+01 \quad(\mathrm{SE}=0.6860)$

STANDARD DEVIATION $=0.3577 \mathrm{E}+04$

\section{AUTOCORRELATIONS OF RESIDUAL}

\begin{tabular}{|c|c|c|c|c|c|c|}
\hline & 0.0587 & 0.0342 & 0.0308 & -0.0987 & -0.0316 & 0.0280 \\
\hline \multirow[t]{2}{*}{ SE } & 0.1400 & 0.1405 & 0.1407 & 0.1408 & 0.1422 & 0.1423 \\
\hline & -0.1067 & 0.0856 & -0.1706 & 0.1734 & 0.1266 & 0.0433 \\
\hline \multirow[t]{2}{*}{ SE } & 0.1424 & 0.1440 & 0.1450 & 0.1488 & 0.1527 & 0.1548 \\
\hline & -0.0953 & -0.0344 & -0.0807 & 0.0343 & 0.0795 & 0.0825 \\
\hline \multirow[t]{2}{*}{ SE } & 0.1550 & 0.1562 & 0.1563 & 0.1571 & 0.1573 & 0.1581 \\
\hline & -0.1090 & 0.0298 & -0.0339 & -0.0960 & 0.0237 & 0.0169 \\
\hline \multirow[t]{2}{*}{ SE } & 0.1589 & 0.1604 & 0.1605 & 0.1606 & 0.1617 & 0.1618 \\
\hline & -0.1480 & 0.0438 & 0.0206 & 0.1163 & 0.1004 & -0.0747 \\
\hline \multirow[t]{2}{*}{ SE } & 0.1618 & 0.1645 & 0.1647 & 0.1648 & 0.1664 & 0.1675 \\
\hline & 0.0422 & -0.0673 & -0.2017 & 0.0010 & -0.0329 & -0.0535 \\
\hline SE & 0.1682 & 0.1684 & 0.1689 & 0.1736 & 0.1736 & 0.1737 \\
\hline
\end{tabular}

THE LJUNG-BOX Q VALUE IS $\quad 7.67$

IF RESIDUALS ARE RANDOM IT SHOULD BE DISTRIBUTED AS CHI-SQUARED (12)

AUTOCORRELATIONS OF SQUARED RESIDUAL

THE LJUNG-BOX Q VALUE IS $\quad 9.64$

IF RESIDUALS ARE RANDOM IT SHOULD BE DISTRIBUTED AS CHI-SQUARED (12)

DERIVATION OF THE COMPONENT MODELS : „THE SPECIFICATION OF SOME OF THE MODELS MAY BE UNRELIABLE" 


\section{MODELS FOR THE COMPONENTS}

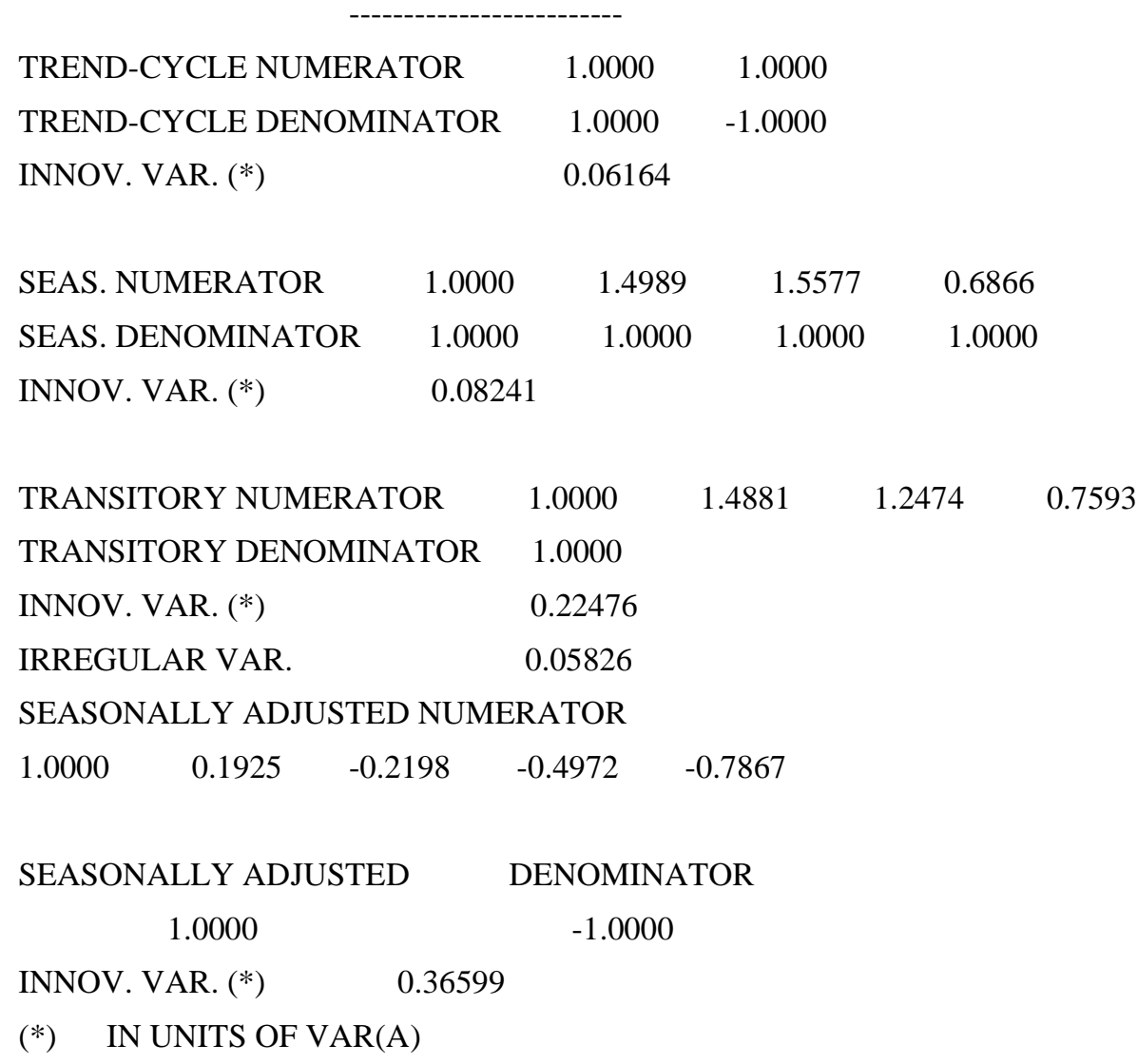

DETERMINISTIC COMPONENT FROM TRAMO

NONE

DERIVATION OF THE FILTERS : OK

COMPONENTS (STATIONARY TRANSFORMATION): SECOND MOMENTS TREND-CYCLE ADJUSTED

LAG COMPONENT ESTIMATOR ESTIMATE COMPONENT ESTIMATOR ESTIMATE

$\begin{array}{lcccccc}\text { LAG1 AUTCOR } & 0.500 & 0.758 & 0.762 & 0.333 & 0.392 & 0.390 \\ \text { LAG4 AUTCOR } & 0.000 & 0.344 & 0.249 & -0.403 & -0.553 & 0.319 \\ \text { VAR. }(*) & 0.123 & 0.031 & 0.027 & 0.714 & 0.684 & 0.510\end{array}$

IRREGULAR

SEASONAL

LAG COMPONENT ESTIMATOR ESTIMATE COMPONENT ESTIMATOR ESTIMATE

$\begin{array}{lllllll}\text { LAG1 AUTCOR } & 0.000 & -0.584 & -0.530 & 0.798 & 0.371 & 0.379\end{array}$

$\begin{array}{lllllll}\text { LAG4 AUTCOR } & 0.000 & -0.160 & -0.319 & 0.000 & 0.112 & -0.018\end{array}$

$\begin{array}{lllllll}\text { VAR. }(*) & 0.058 & 0.011 & 0.008 & 0.506 & 0.031 & 0.024\end{array}$

(*) IN UNITS OF VAR(A)

ESTIMATION ERROR VARIANCE

(In units of $\operatorname{Var}(\mathbf{a}))$ 
FINAL ESTIMATION

ERROR

REVISION IN CON-

CURRENT ERROR

TOTAL ESTIMATION

ERROR (CONCURRENT ESTIMATOR)
TREND-CYCLE ADJUSTED

$$
0.760 \quad 0.088
$$

$0.277 \quad 0.076$

1.037

0.164

PERCENTAGE REDUCTION IN THE STANDARD ERROR OF THE REVISION AFTER ADDITIONAL YEARS (COMPARISON WITH CONCURRENT ESTIMATORS)

$\begin{array}{lll}\text { AFTER 1 YEAR } & 57.45 & 51.82 \\ \text { AFTER 2 YEAR } & 81.87 & 77.57 \\ \text { AFTER 3 YEAR } & 92.51 & 90.55 \\ \text { AFTER 4 YEAR } & 97.01 & 96.38 \\ \text { AFTER 5 YEAR } & 98.82 & 98.66\end{array}$

AVERAGE PERCENTAGE REDUCTION IN RMSE FROM CONCURRENT ADJUSTMENT 14.31

\section{STANDARD ERROR OF THE CONCURRENT RATES OF ESTIMATORS}

(In points of annualized percent growth. Linear approximations)

\begin{tabular}{|c|c|c|c|}
\hline & TREND-CYCLE & SA SERIES & ORIGINAL SERIES \\
\hline PERIOD TO PERIOD GROWTH & $0.379 \mathrm{E}+04$ & $0.159 \mathrm{E}+04$ & \\
\hline OF THE SERIES (T11) & & & \\
\hline (CENTERED) ESTIMATOR & $0.431 \mathrm{E}+04$ & $0.590 \mathrm{E}+04$ & $0.609 \mathrm{E}+04$ \\
\hline
\end{tabular}

\section{SEASONAL COMPONENT}

$\mathrm{X} \quad \mathbf{1 0 . 0 D 2}$

\begin{tabular}{clrrr} 
YEAR & \multicolumn{1}{l}{ 1ST } & \multicolumn{1}{l}{ 2ND } & \multicolumn{1}{l}{ 3RD } & \multicolumn{1}{l}{ 4TH } \\
2008 & -69.692 & -18.638 & 17.910 & 82.186 \\
2009 & -71.009 & -31.435 & 1.675 & 85.382 \\
2010 & -55.386 & -24.835 & -9.093 & 85.223 \\
2011 & -51.324 & -17.589 & -11.454 & 83.037 \\
2012 & -55.919 & -20.295 & -12.436 & 95.452 \\
2013 & -59.953 & -21.140 & -20.765 & 101.784 \\
2014 & -60.778 & -20.306 & -21.192 & 104.546 \\
2015 & -65.116 & -19.466 & -22.377 & 113.065 \\
2016 & -68.289 & -25.942 & -25.763 & 115.212 \\
2017 & -65.179 & -27.941 & -25.504 & 120.775 \\
2018 & -63.070 & -32.224 & -28.102 & 125.336 \\
2019 & -63.896 & -33.232 & -31.213 & 130.733
\end{tabular}

STANDARD ERROR OF SEASONAL

$\begin{array}{lllll}\text { YEAR } & \text { 1ST } & \text { 2ND } & \text { 3RD } & \text { 4TH }\end{array}$ 


\begin{tabular}{|lllll}
2008 & 1446.733 & 1236.431 & 1225.981 & 1208.803 \\
2009 & 1160.935 & 1105.650 & 1099.993 & 1092.754 \\
2010 & 1082.261 & 1067.800 & 1067.025 & 1064.871 \\
2011 & 1063.545 & 1060.619 & 1060.583 & 1060.197 \\
2012 & 1060.065 & 1059.613 & 1059.612 & 1059.565 \\
2013 & 1059.548 & 1059.488 & 1059.488 & 1059.479 \\
2014 & 1059.483 & 1059.488 & 1059.488 & 1059.548 \\
2015 & 1059.565 & 1059.612 & 1059.613 & 1060.065 \\
2016 & 1060.197 & 1060.583 & 1060.619 & 1063.545 \\
2017 & 1064.871 & 1067.025 & 1067.800 & 1082.261 \\
2018 & 1092.754 & 1099.993 & 1105.650 & 1160.935 \\
2019 & 1208.803 & 1225.981 & 1236.431 & 1446.733
\end{tabular}

\begin{tabular}{|ccccc}
\multicolumn{5}{c}{ TRANSITORY COMPONENT } \\
YEAR & \multicolumn{1}{l}{ 1ST } & 2ND & \multicolumn{1}{l}{ 3RD } & \multicolumn{1}{l}{ 4TH } \\
2008 & 5217.233 & 6723.223 & 5603.968 & 441.187 \\
2009 & -6242.254 & -8235.036 & -6391.066 & -3411.979 \\
2010 & -289.267 & -295.748 & -136.891 & 2263.902 \\
2011 & 3064.093 & 3020.574 & 379.967 & -2223.446 \\
2012 & -1020.200 & -333.397 & 1270.432 & 1260.587 \\
2013 & -537.918 & -1158.195 & -1746.726 & -359.113 \\
2014 & 61.991 & -219.043 & -74.298 & -1049.263 \\
2015 & 315.732 & 1262.614 & 379.405 & -175.182 \\
2016 & -2972.818 & -4218.249 & -3817.041 & -3467.858 \\
2017 & -1658.460 & -0.322 & 475.056 & 900.055 \\
2018 & 1030.989 & -89.815 & 244.494 & 113.707 \\
2019 & 42.864 & 1487.886 & 2348.417 & 3376.133
\end{tabular}

STANDARD ERROR OF TRANSITORY COMP.

$\begin{array}{ccccc}\text { YEAR } & \text { 1ST } & \text { 2ND } & \text { 3RD } & \text { 4TH } \\ 2008 & 3056.537 & 3052.552 & 2945.955 & 2783.087 \\ 2009 & 2679.912 & 2671.175 & 2652.968 & 2628.538 \\ 2010 & 2612.142 & 2608.454 & 2606.593 & 2602.855 \\ 2011 & 2599.578 & 2598.820 & 2598.679 & 2597.958 \\ 2012 & 2597.325 & 2597.222 & 2597.208 & 2597.055 \\ 2013 & 2596.952 & 2596.940 & 2596.937 & 2596.893 \\ 2014 & 2596.907 & 2596.937 & 2596.940 & 2596.952 \\ 2015 & 2597.055 & 2597.208 & 2597.222 & 2597.325 \\ 2016 & 2597.958 & 2598.679 & 2598.820 & 2599.578 \\ 2017 & 2602.855 & 2606.593 & 2608.454 & 2612.142 \\ 2018 & 2628.538 & 2652.968 & 2671.175 & 2679.912 \\ 2019 & 2783.087 & 2945.955 & 3052.552 & 3056.537\end{array}$




\begin{tabular}{|ccccc} 
X 10.0D 3 & & & & \\
YEAR & 1ST & 2ND & \multicolumn{1}{l}{ 3RD } & \multicolumn{1}{l}{ 4TH } \\
2008 & 86.110 & 86.728 & 87.060 & 86.322 \\
2009 & 85.364 & 85.634 & 86.378 & 87.224 \\
2010 & 88.627 & 89.701 & 90.458 & 91.733 \\
2011 & 93.101 & 93.863 & 94.001 & 94.564 \\
2012 & 95.639 & 96.294 & 97.146 & 98.143 \\
2013 & 98.589 & 99.050 & 99.996 & 101.030 \\
2014 & 101.758 & 102.688 & 103.666 & 104.342 \\
2015 & 105.403 & 106.520 & 107.327 & 108.101 \\
2016 & 108.751 & 109.775 & 111.086 & 112.423 \\
2017 & 114.271 & 116.158 & 117.716 & 119.548 \\
2018 & 121.302 & 122.650 & 124.338 & 126.053 \\
2019 & 127.495 & 129.114 & 130.775 & 132.231
\end{tabular}

\begin{tabular}{cccccc}
\multicolumn{6}{c}{ STANDARD ERROR OF TREND-CYCLE } \\
YEAR & 1ST & 2ND & 3RD & 4TH \\
2008 & 3642.500 & 3462.133 & 3344.097 & 3264.688 \\
2009 & 3220.065 & 3181.809 & 3154.837 & 3144.401 \\
2010 & 3137.571 & 3129.202 & 3124.768 & 3123.502 \\
2011 & 3122.147 & 3120.553 & 3119.951 & 3119.755 \\
2012 & 3119.471 & 3119.218 & 3119.135 & 3119.096 \\
2013 & 3119.044 & 3119.008 & 3118.994 & 3118.978 \\
2014 & 3118.986 & 3118.994 & 3119.008 & 3119.044 \\
2015 & 3119.096 & 3119.135 & 3119.218 & 3119.471 \\
2016 & 3119.755 & 3119.951 & 3120.553 & 3122.147 \\
2017 & 3123.502 & 3124.768 & 3129.202 & 3137.571 \\
2018 & 3144.401 & 3154.837 & 3181.809 & 3220.065 \\
2019 & 3264.688 & 3344.097 & 3462.133 & 3642.500
\end{tabular}

SEASONALLY ADJUSTED SERIES

\section{10.0D 3}

\begin{tabular}{cccrr} 
YEAR & 1ST & \multicolumn{1}{l}{ 2ND } & \multicolumn{1}{l}{ 3RD } & \multicolumn{1}{l}{ 4TH } \\
2008 & 91.492 & 93.239 & 93.196 & 86.921 \\
2009 & 78.480 & 77.363 & 80.252 & 83.220 \\
2010 & 88.728 & 89.528 & 89.985 & 94.057 \\
2011 & 96.293 & 97.140 & 94.329 & 91.786 \\
2012 & 95.294 & 95.560 & 98.357 & 99.788 \\
2013 & 97.865 & 97.867 & 98.029 & 101.054 \\
2014 & 101.563 & 102.410 & 103.924 & 102.971 \\
2015 & 105.664 & 108.160 & 107.301 & 108.390 \\
2016 & 105.375 & 105.543 & 107.429 & 108.624 \\
2017 & 112.631 & 116.417 & 117.966 & 120.378 \\
2018 & 122.773 & 122.135 & 124.671 & 126.389
\end{tabular}


$\begin{array}{lllll}2019 & 127.264 & 130.761 & 133.041 & 135.805\end{array}$

\begin{tabular}{|ccccc}
\multicolumn{6}{c}{ STANDARD ERROR OF SEASONALLY ADJUSTED SERIES } \\
YEAR & 1ST & 2ND & 3RD & 4TH \\
2008 & 1446.733 & 1236.431 & 1225.981 & 1208.803 \\
2009 & 1160.935 & 1105.650 & 1099.993 & 1092.754 \\
2010 & 1082.261 & 1067.800 & 1067.025 & 1064.871 \\
2011 & 1063.545 & 1060.619 & 1060.583 & 1060.197 \\
2012 & 1060.065 & 1059.613 & 1059.612 & 1059.565 \\
2013 & 1059.548 & 1059.488 & 1059.488 & 1059.479 \\
2014 & 1059.483 & 1059.488 & 1059.488 & 1059.548 \\
2015 & 1059.565 & 1059.612 & 1059.613 & 1060.065 \\
2016 & 1060.197 & 1060.583 & 1060.619 & 1063.545 \\
2017 & 1064.871 & 1067.025 & 1067.800 & 1082.261 \\
2018 & 1092.754 & 1099.993 & 1105.650 & 1160.935 \\
2019 & 1208.803 & 1225.981 & 1236.431 & 1446.733
\end{tabular}

\section{IRREGULAR COMPONENT}

\section{$\begin{array}{lllll}\text { YEAR } & \text { 1ST } & \text { 2ND } & \text { 3RD } & \text { 4TH }\end{array}$}

$\begin{array}{lllll}2008 & 164.527 & -212.974 & 532.715 & 158.184\end{array}$

$\begin{array}{llllll}2009 & -641.282 & -36.114 & 265.643 & -591.464\end{array}$

$\begin{array}{lllll}2010 & 390.209 & 122.652 & -336.139 & 59.925\end{array}$

$\begin{array}{lllll}2011 & 128.289 & 256.550 & -51.869 & -554.036\end{array}$

$\begin{array}{lllll}2012 & 675.694 & -400.775 & -60.005 & 383.783\end{array}$

$\begin{array}{lllll}2013 & -186.473 & -25.415 & -220.538 & 383.175\end{array}$

$2014 \quad-257.243 \quad-59.805 \quad 332.770 \quad-320.986$

$2015 \quad-54.683 \quad 376.934 \quad-405.200 \quad 463.231$

$2016 \quad-402.276 \quad-13.973 \quad 160.226 \quad-331.075$

$2017 \quad 17.949 \quad 259.000 \quad-224.270 \quad-70.672$

$2018 \quad 439.748 \quad-424.895 \quad 88.501 \quad 222.238$

$2019 \quad-274.458 \quad 158.814 \quad-81.833 \quad 197.698$

\section{References}

1. Litman, T. Well Measured: Developing Indicators for Sustainable and Livable Transport Planning. Victoria Transport Policy Institute, Victoria, Canada, 2018. Available online: http://www.vtpi.org/wellmeas.pdf (accessed 18th May 2018).

2. Szaruga, E., Skąpska, E., Załoga, E. i Matwiejczuk, W. Trust and Distress Prediction in Modal Shift Potential of Long-Distance Road Freight in Containers: Modeling Approach in Transport Services for Sustainability. Sustainability 2018, 10 (7), 2370. doi:10.3390/su10072370.

3. Mączyńska, E. Regional Asymmetries - Basis, Consequences and Counter-measures. MAZOWSZE Studia Regionalne 2015, 17, pp. 159-165. 
4. Neoliberalizm jest groźny dla rozwoju kraju (interview with prof. Elżbieta Mączyńska) [into English: Neoliberalism is dangerous for the development of the country]. Rzeczpospolita (published: 15th June 2016).

5. Daly, H. E. Steady-state economics versus growthmania: A critique of the orthodox conceptions of growth, wants, scarcity, and efficiency. Policy Sciences 1974, 5(2), pp. 149-167. doi:10.1007/BF00148038.

6. Latouche, S. Farewell to Growth. Polity Press: Cambridge, Malden, 2009.

7. Mączyńska, E. Potencjał rozwojowy Polski w kontekście hipotezy o nowej sekularnej stagnacji [into English: Poland's development potential in the context of the hypothesis of a new secular stagnation]. Biuletyn PTE 2015, 2(69), pp. 62-69.

8. Łaski, K. Wykłady z makroekonomii. Gospodarka kapitalistyczna bez bezrobocia [into English: Lectures on macroeconomics. Capitalist economy without unemployment]. Osiatyński, J., Ed.; Polish Economy Society: Warsaw, Poland, 2015.

9. Famielec, J. Ekologizacja jako paradygmat rozwoju społeczno-gospodarczego [into English: Ecologization as a paradigm of socio-economic development]. In Ekologizacja gospodarki [into English: Greening the economy], Kożuch, M., Ed. Fundacja Uniwersytetu Ekonomicznego w Krakowie: Kraków, Poland, 2015.

10. Piketty, T. Chronicles. On Our Troubled Times. VIKING an imprint of PENGUIN BOOKS, n.p., 2016.

11. Schmelzer, M. The growth paradigm: History, hegemony, and the contested making of economic growthmanship. Ecological Economics 2015, 118; pp. 262-271. doi:10.1016/j.ecolecon.2015.07.029.

12. Buch-Hansen, H. Capitalist diversity and de-growth trajectories to steady-state economies. Ecological Economics 2014, 106, pp. 167-173. doi:10.1016/j.ecolecon.2014.07.030.

13. Famielec, J. Stanowiony porządek ekologiczny versus spontaniczny ład gospodarczy [into English: Ecological order versus spontaneous economic order]. In Spontaniczne $i$ stanowione elementy ładu gospodarczego w procesie transformacji - dryf ładu czy jego doskonalenie? [into English: Spontaneous and constituted elements of economic order in the transformation process - order drift or improvement?], Pysz, P., Grabska, A., Moszyński, M., Eds.; Polish Economy Society: Warsaw, Poland, 2014.

14. Klein, N. To zmienia wszystko. Kapitalizm kontra klimat [into English: It changes everything. Capitalism versus climate]. Jankowska, H. \& Makaruk, K., Trans.; Warszawskie Wydawnictwo Literackie MUZA SA: Warsaw, Poland, 2016.

15. Potter, W. Green is the New Red: An Insider's Account of a Social Movement Under Siege. City Lights Books: San Francisco, USA, 2011.

16. Petrakis, P. E., Kostis, P. C., Kafka, K. I. Secular stagnation, faltering innovation, and high uncertainty: New-era entrepreneurship appraisal using knowledge-based thinking. Journal of Business Research 2016, 69(5), pp. 1909-1913. doi:10.1016/j.jbusres.2015.10.078.

17. Petrakis, P. E., Konstantakopoulou, D. Uncertainty in Entrepreneurial Decision Making. The Competitive Advantages of Strategic Creativity. Palgrave Macmillan: New York, USA, 2015. doi:10.1057/9781137460790.

18. Rifkin, J., The zero marginal cost society, 2nd ed.; Griffin: New York, USA, 2015.

19. Stiglitz, J.E., Fitoussi, J.-P., Durand, M. Poza PKB: Mierzymy to co ma znaczenie dla rozwoju społecznogospodarczego (in original: Beyond GDP: Measuring What Counts for Economic and Social Performance), 1st ed., Polish Economic Society: Warsaw, Poland, 2019.

20. Schiller, R.J. Finanse a dobrobyt społeczny (in original: Finance and the Good Society), 1st ed., Polish Economic Society: Warsaw, Poland, 2016.

21. Landais, B. Fluktuacje gospodarcze. Nowa synteza (in original: Les fluctuations èconomiques. Une synthèse nouvele, into English: Economic fluctuations. New synthesis), 1st ed.; Publishing House of Jagiellonian University, Publishers: Publishing House of the Poznan University of Economics and Business: Kraków, Poland, 2019.

22. Kotowicz-Jawor, J., Pietrewicz, L., Zajfert, M., Mączyńska, E., Baczko, T., Puchała-Krzywina, E., Grzelońska, U. Innovativeness of Polish Economy in the Transitional Stage of Development, Publisher: Publishing House of University of Łódź: Łódź, Poland, 2019.

23. Álvarez, L. J., Gómez-Loscos, A. A menu on output gap estimation methods. Journal of Policy Modeling 2018, 40, pp. 827-850. doi:10.1016/j.jpolmod.2017.03.008.

24. Ahmad, W., Sharma, S. K. Testing output gap and economic uncertainty as an explicator ofstock market returns. Research in International Business and Finance 2018, 45, pp. 293-306. doi:10.1016/j.ribaf.2017.07.162. 
25. Łyziak, T. Do global output gaps help forecast domestic inflation? Evidence from Phillips curves for Poland. International Journal of Forecasting 2019, 35, pp. 1032-1041. doi:10.1016/j.ijforecast.2019.03.006.

26. Buncic, D., Müller, O. Measuring the output gap in Switzerland with linear opinion pools. Economic Modelling 2017, 64, pp. 153-171. doi:10.1016/j.econmod.2017.03.007.

27. Zhang, C., Murasawa, Y. Output gap measurement and the New Keynesian Phillips curve for China. Economic Modelling 2011, 28, pp. 2462-2468. doi:10.1016/j.econmod.2011.07.003.

28. Pichette, L., Robitaille, M.-N., Salameh, M., St-Amant, P. (2019). Dismiss the output gaps? To use with caution given their limitations. Economic Modelling 2019, 76, pp. 199-215. doi:10.1016/j.econmod.2018.08.001.

29. Marcellino, M., Musso, A. The reliability of real-time estimates of the euro area output gap. Economic Modelling 2011, 28, pp. 1842-1856. doi:10.1016/j.econmod.2011.03.014.

30. Kamada, K. Real-time estimation of the output gap in Japan and its usefulness for inflation forecasting and policymaking. North American Journal of Economics and Finance 2005, 16, pp. 309-332. doi:10.1016/j.najef.2005.05.004.

31. González-Astudillo, M. An output gap measure for the euro area: Exploiting country-level and crosssectional data heterogeneity. European Economic Review 2019, 120, 103301. doi:10.1016/j.euroecorev.2019.103301.

32. Grant, A. L., Chan, J. C. Reconciling output gaps: Unobserved components model and HodrickPrescott filter. Journal of Economic Dynamics $\mathcal{E}$ Control 2017, 75, pp. 114-121. doi:10.1016/j.jedc.2016.12.004.

33. Mise, E., Kim, T.-H., Newbold, P. On suboptimality of the Hodrick-Prescott filter at time series endpoints. Journal of Macroeconomics 2005, 27, pp. 53-67. doi:10.1016/j.jmacro.2003.09.003.

34. Razzak, W. The Hodrick-Prescott technique: A smoother versus a filter. An application to New Zealand GDP. Economics Letters 1997, 57, pp. 163-168.

35. Jašová, M., Moessner, R., Takáts, E. Domestic and global output gaps as inflation drivers: What does the Phillips curve tell? Economic Modelling 2020, 87, pp. 238-253. doi:10.1016/j.econmod.2019.07.025.

36. Ince, O., Papell, D. H. The (un)reliability of real-time output gap estimates with revised data. Economic Modelling 2013, 33, pp. 713-721. doi:10.1016/j.econmod.2013.05.023.

37. Maravall, A., del Río, A. Temporal aggregation, systematic sampling, and the Hodrick-Prescott filter. Computational Statistics E Data Analysis 2007, 52, pp. 975-998. doi:10.1016/j.csda.2007.08.001.

38. Mitra, S., Maheswari, V., Mitra, A. A wavelet filtering based estimation of output gap. Applied Mathematics and Computation 2011, 218, pp. 3710-3722. doi:10.1016/j.amc.2011.09.013.

39. Amador-Torres, J. S., Gomez-Gonzalez, J. E., Ojeda-Joya, J. N., Jaulin-Mendez, O. F., Tenjo-Galarza, F. Mind the gap: Computing finance-neutral output gaps in Latin-American economies. Economic Systems 2016, 40, pp. 444-452. doi:10.1016/j.ecosys.2015.09.007.

40. de Carvalho, M., \& Rua, A. Real-time nowcasting the US output gap: Singular spectrum analysis at work. International Journal of Forecasting 2017, 33, pp. 185-198. doi:10.1016/j.ijforecast.2015.09.004.

41. Gómez, V., Maravall, A. Programs TRAMO (Time Series Regression with ARIMA Noise Missing Observations, and Outliers) and SEATS (Signal Extraction in ARIMA Times Series). Instructions for the User, November $1997 . \quad$ Avaiable online: http://www.bde.es/f/webbde/SES/servicio/Programas_estadisticos_y_econometricos/Programas/fiche ros/manualdos.pdf (accessed on 10 ${ }^{\text {th }}$ July 2016).

42. EuroStat database. Available online: https:/ec.europa.eu/eurostat/data/database/ (accessed on 05 ${ }^{\text {th }}$ April 2020).

43. Hodrick, R.P. Postwar U.S. business cycles: an empirical investigation. J. Money Credit Bank 1997, 29(1), pp. 1-16.

44. Yamanda, H., Jin, L. Japan's output gap estimation and $\ell 1$ trend filtering. Empirical Economics 2013, 45(1), pp. 81-88. doi:10.1007/s00181-012-0625-x.

45. Osiatyński, J., Ed. Collected Works of Michał Kalecki: Capitalism. Business Cycles and Full Employment, Clarendon Press: Oxford, UK, 1990.

46. Block, T.H., Majewski, R.C. Methods and methodology in historical macroeconomics. In Transformational Growth and the Business Cycle, Nell E.J., Ed., Routledge: London, UK, 2005.

47. Taleb, N.N. Czarny Łabędź: o skutkach nieprzewidywalnych zdarzeń [in original: The black swan: the impact of the highly improbable], Kurhaus Publishing: Warsaw, Poland, 2015. 